\title{
Nodularin, a cyanobacterial toxin, is synthesized in planta by symbiotic Nostoc sp.
}

\author{
Michelle M Gehringer ${ }^{1,2}$, Lewis Adler ${ }^{3}$, Alexandra A Roberts ${ }^{1}$, Michelle C Moffitt ${ }^{4}$, \\ Troco K Mihali ${ }^{1}$, Toby JT Mills ${ }^{1}$, Claus Fieker ${ }^{5}$ and Brett A Neilan ${ }^{1}$ \\ ${ }^{1}$ School of Biotechnology and Biomolecular Sciences, University of New South Wales, Sydney, New South \\ Wales, Australia; ${ }^{2}$ Department of Plant Ecology and Systematics, Technical University of Kaiserslautern, \\ Kaiserslautern, Germany; ${ }^{3}$ Bioanalytical Mass Spectrometry Facility, University of New South Wales, Sydney, \\ New South Wales, Australia; ${ }^{4}$ School of Biomedical and Health Sciences, University of Western Sydney, \\ Sydney, New South Wales, Australia and ${ }^{5}$ School of Mathematics and Statistics, University of Sydney, \\ Sydney, New South Wales, Australia
}

\begin{abstract}
The nitrogen-fixing bacterium, Nostoc, is a commonly occurring cyanobacterium often found in symbiotic associations. We investigated the potential of cycad cyanobacterial endosymbionts to synthesize microcystin/nodularin. Endosymbiont DNA was screened for the aminotransferase domain of the toxin biosynthesis gene clusters. Five endosymbionts carrying the gene were screened for bioactivity. Extracts of two isolates inhibited protein phosphatase 2A and were further analyzed using electrospray ionization mass spectrometry (ESI-MS)/MS. Nostoc sp. 'Macrozamia riedlei 65.1' and Nostoc sp. 'Macrozamia serpentina 73.1' both contained nodularin. High performance liquid chromatography (HPLC) HESI-MS/MS analysis confirmed the presence of nodularin at $9.55 \pm 2.4 \mathrm{ng} \mu \mathrm{g}-1$ chlorophyll $a$ in Nostoc sp. 'Macrozamia riedlei 65.1' and $12.5 \pm 8.4 \mathrm{ng} \mu \mathrm{g}-1 \mathrm{Chl} a$ in Nostoc sp. 'Macrozamia serpentina 73.1' extracts. Further scans indicated the presence of the rare isoform [L-Har $\left.{ }^{2}\right]$ nodularin, which contains L-homoarginine instead of L-arginine. Nodularin was also present at $1.34 \pm 0.74 \mathrm{ng} \mathrm{ml}^{-1}$ (approximately $3 \mathrm{pmol}$ per $\mathrm{g}$ plant ww) in the methanol root extracts of $M$. riedlei MZ65, while the presence of [L-Har ${ }^{2}$ ] nodularin in the roots of $M$. serpentina MZ73 was suggested by HPLC HESI-MS/MS analysis. The ndaA-B and ndaF genomic regions were sequenced to confirm the presence of the hybrid polyketide/nonribosomal gene cluster. A seven amino-acid insertion into the NdaA-C1 domain of $N$. spumigena NSOR10 protein was observed in all endosymbiont-derived sequences, suggesting the transfer of the nda cluster from $N$. spumigena to terrestrial Nostoc species. This study demonstrates the synthesis of nodularin and [L-Har $\left.{ }^{2}\right]$ nodularin in a non-Nodularia species and the production of cyanobacterial hepatotoxin by a symbiont in planta.
\end{abstract}

The ISME Journal (2012) 6, 1834-1847; doi:10.1038/ismej.2012.25; published online 29 March 2012

Subject Category: microbe-microbe and microbe-host interactions

Keywords: cyanobacteria; cycad; symbiosis; nodularin; Nostoc

\section{Introduction}

Toxin-producing cyanobacteria are recognized as a threat to public health globally, particularly in regions without access to high quality potable water. Increased aquatic eutrophication has resulted in massive blooms of cyanobacteria both in freshwater and marine environments. The most commonly produced cyanobacterial toxins are the hepatotoxins, microcystin and nodularin (Fristachi and Sinclair, 2008), both capable of inhibiting protein phosphatase 1 and $2 \mathrm{~A}$ to varying degrees

Correspondence: BA Neilan or MM Gehringer, School of Biotechnology and Biomolecular Sciences, University of New South Wales, Sydney, New South Wales 2052, Australia.

E-mail: b.neilan@unsw.edu.au or mgehringer@unsw.edu.au

Received 14 November 2011; revised 8 February 2012; accepted 10 February 2012; published online 29 March 2012
(Mackintosh et al., 1990) and inducing protein hyperphosphorylation, cytoskeletal collapse and massive hepatic bleeding (Kuiper-Goodman et al., 1999). Both toxins are also recognized as potential tumor promoters and carcinogens, and hence it is of importance to identify the production of these toxins in the environment to eliminate even lowlevel exposure to humans (Humpage, 2008).

Nodularin is a cyclic pentapeptide (Figure 1) synthesized by the planktonic cyanobacterial species Nodularia spumigena and the benthic species Nodularia sphaerocarpa PCC7804 (Beattie et al., 2000; Moffitt et al., 2001). It occurs primarily in brackish water blooms worldwide, including the Baltic Sea and coastal waters off New Zealand, Australia, South Africa and the United Kingdom (Beattie et al., 2000). Variants of the nodularin toxin have been reported, namely [L-Har $\left.{ }^{2}\right]$ nodularin (Beattie et al., 2000; Saito et al., 
2001), [6(Z)-Adda $\left.{ }^{3}\right]$ nodularin, [D-Asp $\left.{ }^{1}\right]$ nodularin and [DMAdda ${ }^{3}$ nodularin (Namikoshi et al., 1994). The toxin motuporin, isolated from the marine sponge Theonella swinhoei, is thought to be another

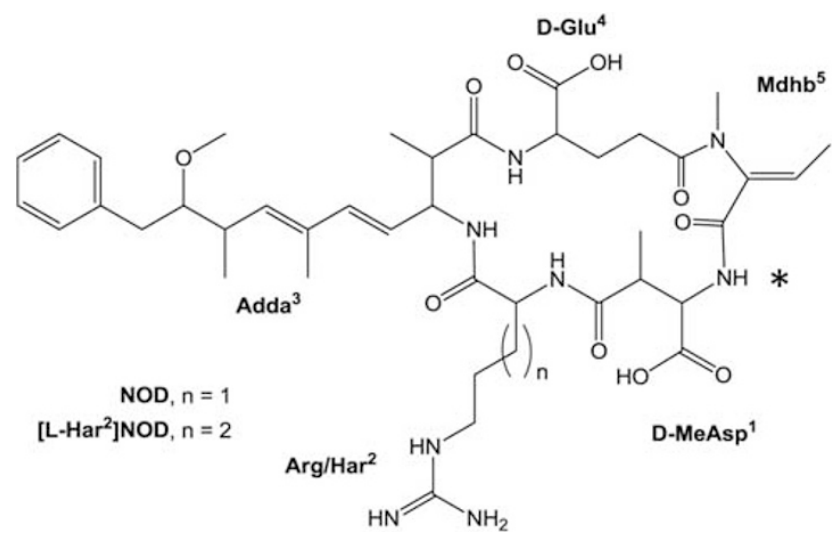

Figure 1 The chemical structure of the pentapeptide nodularin and its variant $\left[\mathrm{L}-\mathrm{Har}^{2}\right]$ nodularin indicating the numbering of the amino acids. The * indicates where the additional amino acids, D-alanine and D-leucine are inserted for the heptapeptide toxin, microcystin. Adda, $(2 S, 3 S, 8 S, 9 S)$-3-amino9-methoxy-2,6,8-trimethyl-10-phenyldeca-4 $(E), 6(E)$-dienoic acid; Arg, arginine; D-Glu, D-glutamate; D-MeAsp, D-erythro- $\beta$-methylaspartic acid; Har, homoarginine; Mdhb, N-methyldehydrobutyrine (Rinehart et al., 1988). variant. It has arginine replaced by valine at position 2 (De Silva et al., 1992). The producer of this toxin is unknown but thought to be a cyanobacterial symbiont. Nodularin synthesis has not been reported in any other cyanobacterial genus. Conversely, numerous cyanobacterial genera, including Microcystis, Anabaena, Phormidium, Nostoc and Planktothrix, produce the heptapeptide microcystin-LR, similar in structure to nodularin with an additional two amino-acid residues, D-alanine and D-leucine, and with $N$-methyldehydroalanine replacing $N$-methyldehydrobutyrine (Rinehart et al., 1988).

Nodularins and microcystins are biosynthesized via modular megasynthases (Figure 2A), which consists of both non-ribosomal peptide synthetase (NRPS) and polyketide synthase (PKS) modules (Tillett et al., 2000; Moffitt and Neilan, 2004). Each module contains enzymatic domains responsible for substrate selection and activation, modification and condensation. Within NRPS modules these functions are catalyzed by adenylation, thiolation, methyltransferase, epimerase and condensation domains. The 48-kb gene cluster encoding the synthesis of nodularin (nda) (Moffitt and Neilan, 2004) resembles the microcystin synthetase cluster (mcy) (Tillett et al., 2000), with the exception of two NRPS modules that are absent in nda (Figure 2A). Christiansen et al.

A Microcystin (mcy) gene cluster: Microcystis aeruginosa PCC7806, 55 kb.

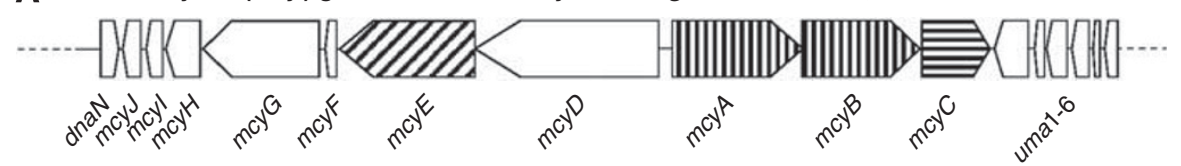

Nodularin (nda) gene cluster: Nodularia spumigena NSOR10, 48 kb.

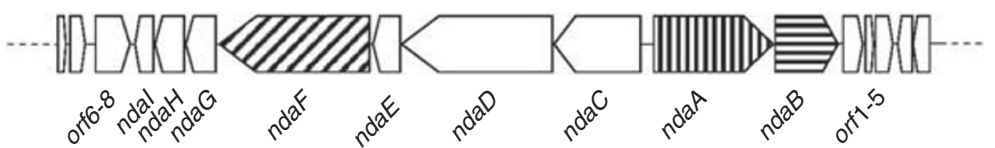

B a $n d a A$

\begin{tabular}{|c|c|c|c|c|}
\hline$A 1$ & $T$ & $C 1$ & $c 1 b$ & $A 2$ \\
\hline 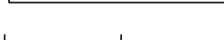 & & & & \\
\hline
\end{tabular}

b

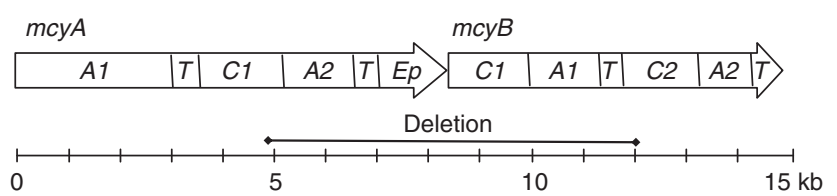

Figure 2 (A) The diagrammatic representation of the regions of the microcystin and nodularin gene clusters, of M. aeruginosa PCC7806 and Nodularia spumigena NSOR10, respectively, investigated in this study. Primers HEPF/HEPR (Jungblut and Neilan, 2006) were used to target the aminotransferase region of the mcyE and $n d a F$ genes (diagonal hatching). Analysis of the evolutionary relationship between nda and mcy gene clusters was performed on the $n d a A$ and $m c y A / B$ gene regions indicated by perpendicular hatching. Analysis of the adenylationbinding domain encoded by $n d a B$ and mcyC (horizontal hatching) was also performed. The diagram is not drawn to scale. (B) A diagram representing the nodularin biosynthetic gene, ndaA, and its proposed evolution from the microcystin biosynthetic genes mcy $A$ and $m c y B$. Each gene encodes two non-ribosomal peptide synthetase (NRPS) modules. The approximate size and location of the encoded adenylation (A), condensation (C), thiolation (T), epimerase (Ep) domains within each module is shown and numbered according to their order of appearance. (a) The nodularin synthetase gene, ndaA, contains two partial condensation domains, C1a and C1b, that are proposed to have evolved from mcyA-C1 and mcyB-C2 following deletion of a fragment from the microcystin biosynthetic gene cluster. Forward and reverse primers, designed in this study for the amplification and sequencing of the Nostoc ndaA condensation domain, are indicated by the arrows. (b) The region from mcyA-C1 and mсyB-C2 (solid line) is proposed to have been deleted during the evolution of the ndaA gene. 
(2003) proposed that the mcy gene cluster arose from an insertion of two additional activation domains into the nda cluster. In contrast, investigation of the co-evolution of housekeeping genes and the toxin gene clusters (Rantala et al., 2004) and the complete gene cluster (Moffitt and Neilan, 2004) suggested that the nda cluster arose from an ancestral mcy cluster by a deletion event spanning the condensation domain of the first module of mcyA (mcyA-C1) to the condensation domain of the first module of $m c y B$ (mcyB-C1) (Figure 2B). The plasticity of the mcy gene cluster is well known, with various deletions and recombination events allowing the synthesis of a diverse array of microcystin variants. Deletion mutants of the $N$-methyltransferase domain of mcy $A$ in microcystin producing Anabaena strains were still able to synthesize microcystin (Fewer et al., 2008). Independent recombination of adenylation domains without their associated condensation domains resulted in the generation of functional new peptide synthetases (Fewer et al., 2007), thereby confirming that gene reorganization is a common means of diversification of non-ribosomal peptide synthesis in the cyanobacteria.

Nostoc strains are known to associate symbiotically with a wide range of hosts, such as diatoms, bryophytes (lichens and hornworts), pteridophytes (Azolla), gymnosperms (cycads) and angiosperms (Gunnera) (Rai et al., 2000; Bergman et al., 2007). A total of 24 endosymbiont species, mostly Nostoc spp., were recently isolated from the coralloid roots of 74 cycad plants (Gehringer et al., 2010). It has been previously demonstrated that the symbiotic cyanobacteria in Macrozamia riedlei, while photosynthetically inactive, fixed nitrogen and transferred it to the host cycad plant in the form of citrulline and glutamine (Lindblad et al., 1991). Microcystin-producing Nostoc symbionts of lichens have also been identified (Oksanen et al., 2004; Kaasalainen et al., 2009), with both strains producing several variants of microcystin. Microcystins are known to disrupt many plant physiological processes, including $\mathrm{CO}_{2}$ fixation, sucrose synthesis, starch storage (McElhiney et al., 2001) and photosynthesis (Abe et al., 1996; Pflugmacher et al., 2007) by inhibiting plant protein phosphatases (Peuthert et al., 2008). Microcystin and nodularin exposure causes oxidative stress and stunted growth in plants exposed to the toxin in the rhizosphere (Gehringer et al., 2003; Lehtimaki et al., 2011), as well as inhibiting germination and seedling growth of several agricultural plants (Saqrane et al., 2008). Accumulation of microcystin and nodularin has also been shown in plants irrigated with toxincontaining water (Mohamed and Al Shehri, 2009). The aims of the present study were to identify the potential for hepatotoxin production in commonly occurring terrestrial cyanobacterial species known to associate with gymnosperms (Cycadaceae), given the evidence that lichen symbionts are capable of synthesizing microcystin (Oksanen et al., 2004; Kaasalainen et al., 2009). In addition, we wished to determine whether this toxin was produced in planta and, if so, whether the levels of toxin production were high enough to affect plant physiology.

\section{Materials and methods}

\section{Culture conditions}

Cyanobacterial isolates (Gehringer et al., 2010) were grown on BG11 medium and incubated at $22^{\circ} \mathrm{C}$ on a 16:8 h light:dark cycle of 2000 lux. Isolates used for toxin detection were grown in $500 \mathrm{ml}$ flasks with gentle agitation as above. Cells were harvested in late exponential phase (day 10).

\section{Toxin biosynthesis gene detection}

DNA was extracted from fresh culture material using the XS buffer extraction method (Tillett and Neilan, 2000) and screened using the primer pair $\mathrm{HEPF} / \mathrm{R}$ targeting the mcyE/ndaF gene (Jungblut and Neilan, 2006; Figure 2A). Briefly, $50 \mathrm{ng}$ of DNA was used in a $20 \mu \mathrm{l}$ reaction containing 5 pmol of each primer, $1 \times$ F1 Taq polymerase buffer, 0.2 U F1 Taq (Fisher Biotec, Wembley, WA, USA), $200 \mu \mathrm{M}$ of each deoxynucleotide triphosphate and $2.5 \mathrm{mM} \mathrm{MgCl}_{2}$. The reaction was heated to $95^{\circ} \mathrm{C}$ for $2 \mathrm{~min}$ followed by 35 cycles of $30 \mathrm{~s}$ at $95^{\circ} \mathrm{C}, 40 \mathrm{~s}$ at $55^{\circ} \mathrm{C}$ and $50 \mathrm{~s}$ at $72^{\circ} \mathrm{C}$ with a final extension of $5 \mathrm{~min}$ at $72^{\circ} \mathrm{C}$. PCR products were precipitated (Gehringer et al., 2010) and sequenced using the PRISM Big Dye Terminator V3.1 system (Applied Biosystems, Mulgrave, VIC, Australia). Total genomic plant DNA was extracted from the leaves of the cycad plants containing toxin-producing symbiont species, using the Qiagen Plant DNAEasy Kit (Qiagen, Hilden, Germany) following the manufacturer's instructions. This DNA was used as a negative control for the HEPF/R PCR.

\section{Characterization of the Nostoc nda cluster via gene walking}

Elucidation of the unknown regions of DNA flanking the putative nodularin aminotransferase biosynthesis gene of ndaF, as well as the complete nda $A$ and $n d a B$ genes, were determined by an adaptor-mediated (pan-handle) PCR method that was modified as previously described (Siebert et al., 1995). A detailed description is provided in the supporting text. The $n d a A$ and $n d a B$ genes were identified using universal degenerate primers (MTF2: 5'-GCNGG(C/T)GG(C/T)GCNTA(C/T)GTNCC-3' and MTR: 5'-GCNGG(C/T)GG(C/T)GCNTA(C/T)GTN CC-3') targeting peptide synthetases (Neilan et al., 1999). The primer pair NdaA C1F2 (5'-GACGAATC AAAATGGCGAAT- $3^{\prime}$ ) and NdaA C1bR (5'-AATTGG CTGGAAGATGCAAG-3') was designed from the ndaA sequence (Figure 2B) obtained from Nostoc sp. ' $M$. serpentina $73.1^{\prime}$ to amplify the partial 
condensation domain sequences. The primers were used at $5 \mathrm{pmol}$ each in a $20 \mu \mathrm{l}$ reaction containing $100 \mathrm{ng}$ of DNA, $1 \times$ F1 Taq polymerase buffer, $0.2 \mathrm{U}$ F1 Taq (Fisher Biotech), $200 \mu \mathrm{M}$ of each dNTP and $2.5 \mathrm{mM} \mathrm{MgCl}_{2}$. The amplification cycle was initially $2 \mathrm{~min}$ at $95^{\circ} \mathrm{C}$ followed by 30 cycles of $20 \mathrm{~s}$ at $95^{\circ} \mathrm{C}$, $20 \mathrm{~s}$ at $58^{\circ} \mathrm{C}$ and $90 \mathrm{~s}$ at $72^{\circ} \mathrm{C}$ with a final extension of $5 \mathrm{~min}$ at $72^{\circ} \mathrm{C}$. PCR products were precipitated and sequenced with both primers as described above.

\section{DNA and amino-acid sequence analysis}

The aminotransferase gene sequences and the $16 \mathrm{~S}$ rRNA gene sequences of the isolates carrying the $m c y E / n d a F$ genes, those of their nearest neighbors and representative reference strains were aligned using Clustal W (Thompson et al., 1997), end gaps removed and the sequences re-aligned. Pairwise percentage identities were calculated for sequences within the alignments. Maximum likelihood trees were generated using the PhyML-3 package (Guindon et al., 2009) using the HKY85 substitution model with 1000 bootstrap resampling events. No amplification products were obtained from plant DNA using the HEPF/R primer pair. The NRPS/PKS analysis tool available at http://nrps.igs.umaryland.edu/nrps/ (Bachman and Ravel, 2009) identified the location of the NRPS domain sequences. The duplicated region within the ndaA condensation domain and previously described conserved core motifs (Rausch et al., 2007) were identified manually using the Ugene program (http://ugene.unipro.ru/). The Nodularia spumigena NSOR10 and Nostoc sp. 'M. serpentina 73.1' nodularin synthetase protein $\mathrm{NdaA}$ contains a condensation domain sequence NdaA-C1, located at positions 1278-1711 and 1292-1731, respectively. A second partially duplicated condensation domain, identified downstream of NdaA-C1, NdaA-C1b was located between 1712 and 1973 and 1732 and 2017 in Nodularia spumigena NSOR10 and Nostoc sp. 73.1, respectively. The Microcystis aeruginosa PCC7806 condensation domain of McyA, McyAC1, was located between positions 1280 and 1706, and the second condensation domain of McyB, McyB-C2, was located between positions 1062 and 1492. The binding pocket sequences for the adenylation domain binding pockets of $\mathrm{NdaB}$ and McyC for the strains, indicated in Table 1, were determined using the NRPS/PKS synthase analysis tool available at http://nrps.igs.umaryland.edu/nrps/ (Bachman and Ravel 2009, p189) and the NRPS predicter tool (Rausch et al., 2005). Using a statistical model of multiple protein alignments, the software predicts PKS and NRPS units from an input protein sequence. It then identifies the potential eight amino-acid specificity domain derived from a database of NRPS adenylation domains previously characterized biochemically. Sequences generated in this project have been deposited in GenBank with accession numbers listed in Table 1.
Protein phosphatase 2A (PP2A) inhibition assay

A bioassay was performed on cyanobacterial extracts to determine whether the five isolates carrying the $m c y E / n d a F$ gene regions were producing bioactive toxin or not. Approximately $500 \mathrm{mg}$ of fresh culture material of these five isolates were resuspended in $500 \mu \mathrm{l}$ of $70 \%$ methanol and lyzed by bead beating (FastPrep, Savant, Thermo Fisher Scientific, Waltham, MA, USA). After centrifugation to remove cell debris, the supernatant was extracted with an equal volume of chloroform and used in the colorimetric PP2A inhibition assay, as described in Ward et al. (1997) and detailed in the supplementary text.

\section{In vitro toxin identification}

As both microcystin and nodularin inhibit PP2A, it was necessary to identify which toxin was present in those samples showing bioactivity. Extracts shown to inhibit PP2A were desiccated and resuspended in $45 \%$ methanol for the identification using electrospray ionization mass spectrometry (ESI-MS). Samples were analyzed using an Ultima API hybrid QTof tandem mass spectrometer (Micromass, Manchester, UK) instrument via nanospray injection into the ESI source. The mass spectra between 100 and $1500 \mathrm{mz}^{-1}$ were acquired in the positive ion mode with a capillary voltage of $3 \mathrm{kV}$. Major species were subjected to ESI-MS/MS analysis by increasing the collision energy to $60 \mathrm{eV}$ in order to identify the product ions and deduce the compound structure (Mazur-Marzec et al., 2006).

New extracts of fresh culture material were made for HESI-MS/MS analysis. Approximately $500 \mathrm{mg}$ of cells from the Nostoc spp. cultures were resuspended in $500 \mu \mathrm{l}$ of $90 \%$ methanol. Cells were disrupted in a FastPrep bead beater (Savant) and stored in the dark overnight. The cell debris was pelleted by centrifugation and the $\mathrm{OD}_{665}$ reading of the cleared extract was taken to determine the chlorophyll a $\left(\begin{array}{lll}C h l & a\end{array}\right)$ content (Meeks and Castenholz, 1971). One millitre of $70 \%$ methanol was added to the remaining cell debris and left overnight to complete the toxin extraction. Both the 70 and $90 \%$ methanol extracts were pooled, diluted 1:3 in water and concentrated on a C18 column (Spoof et al., 2003).

The uncertainty of detection is reported as a $95 \%$ confidence interval, based on the standard deviation of the mean. A calibration equation was derived from the linear regression of five nodularin standard solutions. The standard errors of the estimated concentrations from the calibration equation were between 5 and $9 \%$.

\section{In planta toxin identification}

In order to determine if toxin was produced in planta, approximately $500 \mathrm{mg}$ of the green cyanobiont ring, containing both plant root material and cyanobionts, was extracted with $1 \mathrm{ml}$ of $70 \%$ 


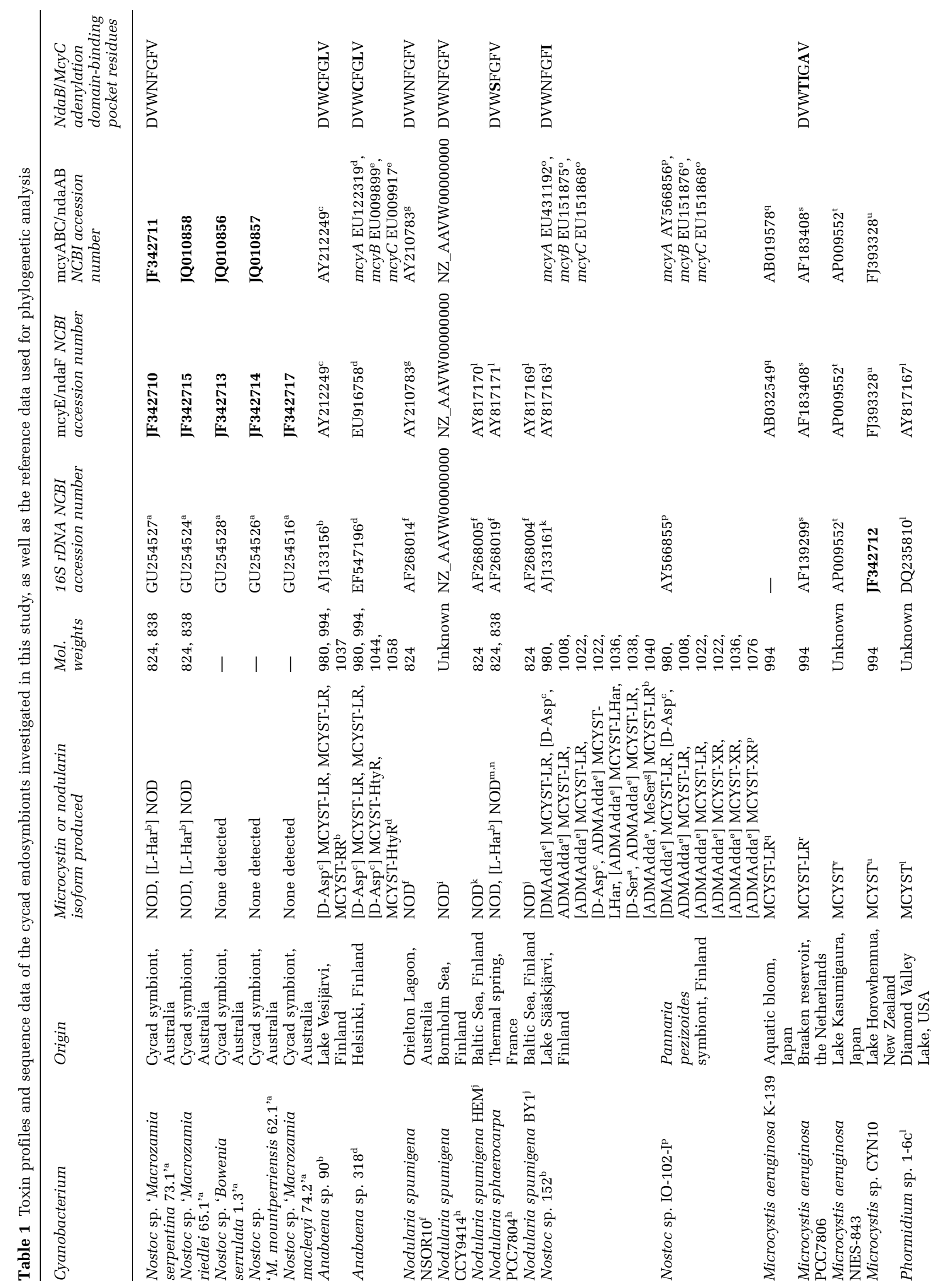


methanol, diluted 1:3 in water, loaded onto preconditioned Sep-Pak C18 classic cartridges (Waters Corporation, Milford, MA, USA) and eluted with $90 \%(\mathrm{v} / \mathrm{v})$ methanol. Following the solid phase extraction clean up, the eluents were filtered through Millex-HV 0.45 $\mu \mathrm{m}$ PVDF filters (Millipore, Billerica, MA, USA) (Spoof et al., 2003). Toxic compounds were separated using reversed phase high performance liquid chromatography (HPLC) and identified using an Orbitrap LTQ XL (Thermo Fisher Scientific) ion trap mass spectrometer using a HESI source. The multiple reaction monitoring product ions used were determined from a commercial nodularin standard and from the ESI-MS/ MS data for [L-Har $\left.{ }^{2}\right]$ nodularin.

\section{Results}

Detection of mcyE/ndaF and phylogenetic analysis A total of 47 surviving cyanobacterial isolates including 44 Nostoc (19 strains) and 3 Calothrix isolates obtained during a previous cyanobiont diversity study (Table 2 in Gehringer et al., 2010) were screened for the presence of the mcyE/ndaF toxin biosynthesis gene essential for microcystin or nodularin synthesis, respectively. Five of the isolates were found to contain regions indicative of the presence of the mcy or nda gene clusters responsible for the non-ribosomal synthesis of these toxins (Table 1). Neither an amplification product was obtained for the remaining 42 isolates nor for plant DNA controls. Phylogenetic analysis of the DNA sequences was performed to obtain an indication of the nature of potential toxin biosynthesis in these isolates. Three of the isolates clustered with the mcyE gene sequences of Anabaena sp. 90 and Anabaena sp. 318, both known to produce microcystin (Figure 3a, Table 1), with a high degree of statistical support (69\%). This cluster was linked to the nodularin-producing cluster of $n d a F$ sequences from Nodularia species and another symbiont Nostoc sp. (52\% support at node). The sequence of the aminotransferase domain from Nostoc sp. 'Macrozamia macleayi 74.2' was placed within the phylogenetic branch of mcyE genes from microcystin-producing Microcystis species (Figure 3a). None of the cyanobiont species grouped within the cluster of nodularin producers. Of interest is the positioning of the AMT region of Nostoc sp. 152, a known microcystin producer, with the nodularin producing Nodularia spp. Four of the sequences obtained from the endosymbiont Nostoc spp., namely JF342710, JF342713, JF342714 and JF342715 (Table 1), had deletions within the sequenced regions of the aminotransferase domains that could result in frameshifts and potentially inactivate biosynthesis.

Phylogenetic analysis of 16S rRNA genes from hepatotoxic genera (Figure $3 \mathrm{~b}$ ) clearly separated the filamentous genera of cyanobacteria, namely 
Table 2 Summary of the quantification of nodularin production in methanol extracts of toxin producing endosymbionts and the coralloid roots from which they were isolated

\begin{tabular}{|c|c|c|c|c|}
\hline $\begin{array}{l}\text { Samples for methanol } \\
\text { extraction and toxin analysis }\end{array}$ & $\begin{array}{l}\text { Total nodularin } \\
\text { per } \mathrm{ng} \mathrm{ml}^{-1} \text { extract }\end{array}$ & $\begin{array}{l}\text { Nodularin in } \\
n g \mu g^{-1} \text { Chl a }\end{array}$ & $\begin{array}{l}\text { Nodularin } \\
\text { per } g w w\end{array}$ & $\begin{array}{l}{\left[L-\text { Har }^{2}\right]} \\
\text { nodularin }\end{array}$ \\
\hline Nostoc sp. 'M. riedlei 65.1' & $173 \pm 45$ & $9.55 \pm 2.4$ & $346 \mathrm{ng}^{\mathrm{a}}$ & Yes \\
\hline Nostoc sp. 'M. serpentine 73.1' & $116 \pm 78$ & $12.5 \pm 8.4$ & $232 \mathrm{ng}^{\mathrm{a}}$ & Yes \\
\hline M. riedlei MZ 65 coralloid root & $1.34 \pm 0.74$ & ND & $3 \mathrm{pmol}^{\mathrm{b}}$ & No \\
\hline M. serpentine MZ 73 coralloid root & BDL & ND & & Yes \\
\hline
\end{tabular}

Abbreviations: BDL, below the detection limit; ND, not determined. The final column indicates whether the presence of [L-Har $\left.{ }^{2}\right]$ nodularin was indicated or not. One $\mathrm{ml}$ of extract was obtained from each sample of approximately $500 \mathrm{mg} .{ }^{a}$ Approximate nodularin content as cells contained copious amounts of EPS; ${ }^{b}$ Approximate amount of toxin per g plant ww as material contained both plant and bacterial matter.

a

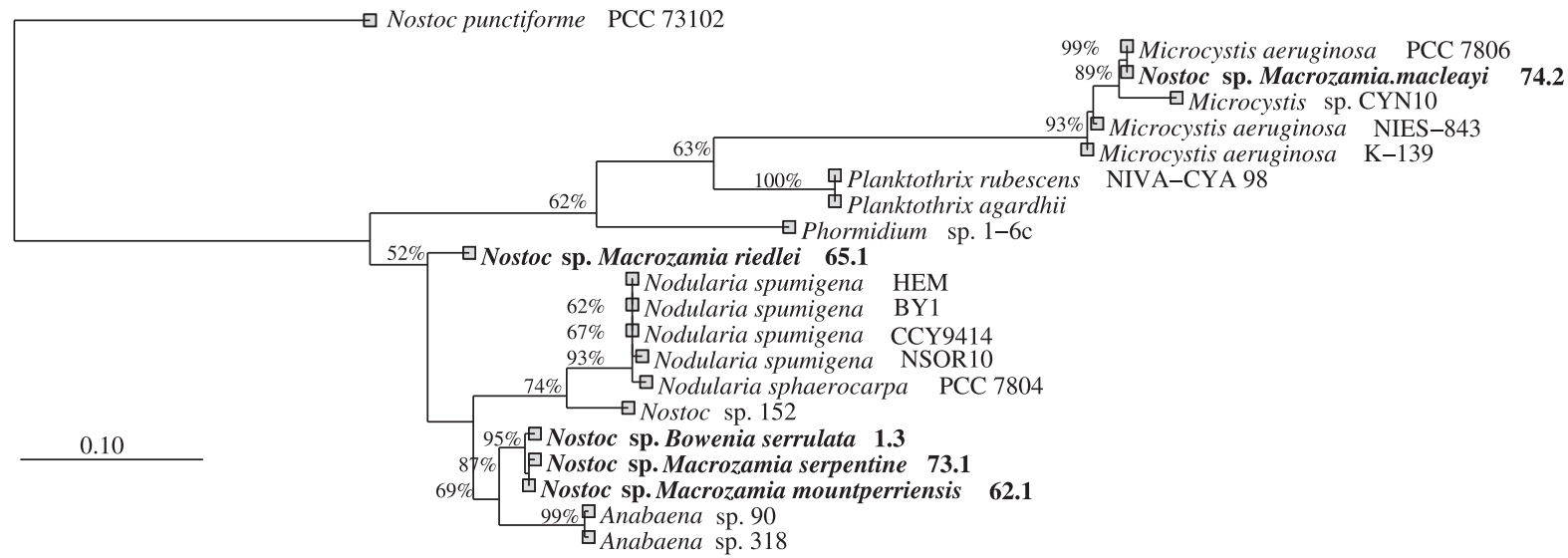

b

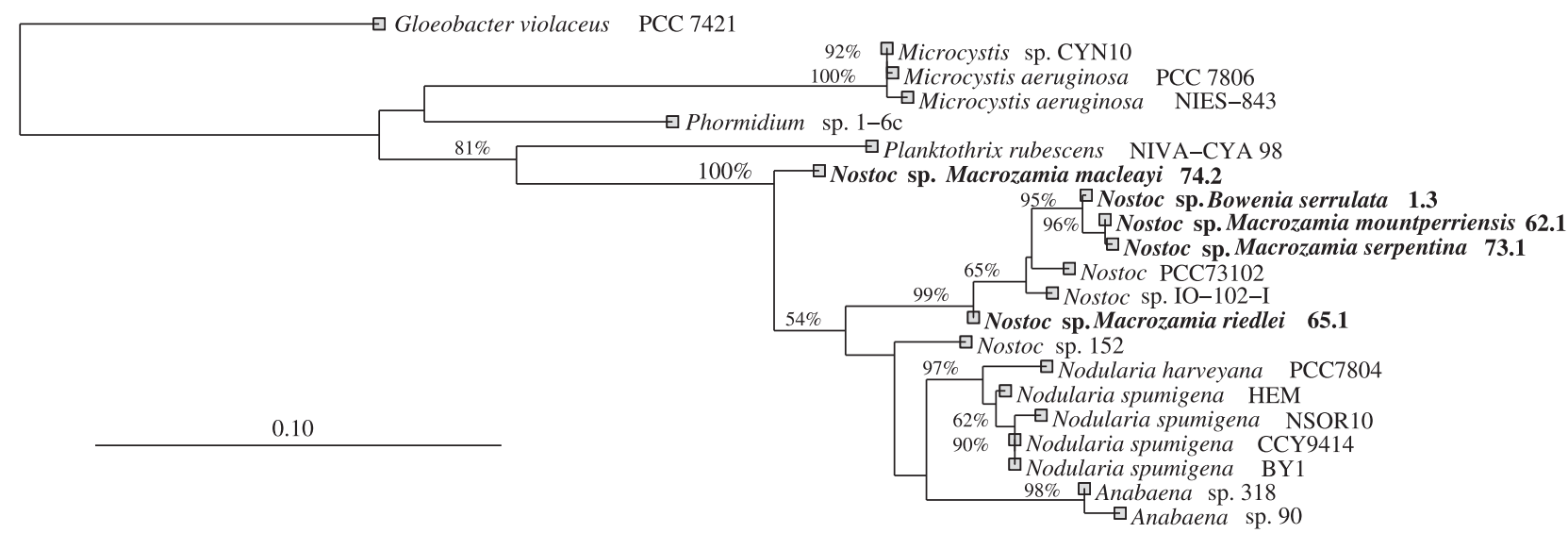

Figure 3 Maximum likelihood phylogenetic tree representing genetic similarities between potential toxin-producing Nostoc spp. and reference strains. (a) $m c y E / n d a F$ sequence analysis of a 440-bp fragment of the aminotransferase region; (b) Partial 16S rRNA gene sequence comparison of a 770-bp fragment. Support values greater than 50\% (1000 bootstrap events) are presented. Sequences in bold were generated during this study.

Phormidium, Planktothrix, Nostoc, Nodularia and Anabaena, from the unicellular microcystinproducing genus Microcystis. Within the filamentous cluster each species grouped coherently. The two microcystin-producing Anabaena species grouped with the nodularin-producing Nodularia species, followed by the Nostoc clade comprised of non-toxic (Nostoc PCC73102), microcystinproducing (Nostoc sp. IO-102-I and Nostoc sp. 152) and nodularin-producing Nostoc species (Nostoc sp.
'Macrozamia serpentina 73.1' and Nostoc sp. 'Macrozamia riedlei 65.1').

Molecular analysis of the Nostoc nodularin cluster Sequencing of key genes in the non-ribosomal gene cluster would provide information regarding the biosynthetic product of the gene cluster. Pan-handle PCR and sequencing of the genetic region surrounding the AMT domain analyzed above and the 
NRPS-encoding genes of Nostoc sp. 'M. serpentina 73.1' (Table 1), indicated the presence of three open reading frames, encoding three NRPS modules and one hybrid NRPS/PKS module. The domain structure of the modules was identical with the corresponding modules in N. spumigena NSOR10 within proteins NdaA and NdaB. This analysis implied that Nostoc sp. 'M. serpentina 73.1' produced nodularin and that additional chemical analysis was necessary to confirm this.

Further analysis of amino-acid residues that line the binding pocket of the adenylation domains and contribute to substrate specificity was performed (Challis et al., 2000). The $\mathrm{NdaB}$ adenylation domain carries binding pocket residues that are important in incorporating L-Arg or L-Har residues into nodularin. The binding pocket residues in Nostoc sp. ' $M$. serpentina 73.1' were identical to those found in $N$. spumigena NSOR10 and N. spumigena CCY9414 (Table 1), further supporting the hypothesis that this strain produces nodularin, rather than microcystin.

Previously, we proposed that the nda gene cluster evolved from the mcy cluster following deletion of a gene fragment encoding two NRPS modules from within the mcyA and mcyB genes (Figure 2A) (Moffitt and Neilan, 2004). This hypothesis is based on the identification that within the condensation domain of the NdaA NRPS module (NdaA-C), highly conserved motifs are repeated. The protein sequence before and after the domain repeat of Nostoc sp. 'Macrozamia serpentina 73.1' (referred to as NdaAC1 and NdaA-C1b) was homologous to McyA-C and McyB-C2, respectively. As previous analyses have been restricted to the nda cluster from N. spumigena, we used this as an opportunity to further investigate this theory using the nda genes of the Nostoc strains. Newly designed primers targeting the condensation domains within the ndaA gene (Supplementary Figure S1B) were used to determine the partial condensation domain sequence in the four $n d a F$ carrying endosymbiont species of Nostoc. Alignment of the DNA sequences for the region spanning the condensation motif repeat for Nostoc spp. 'Macrozamia serpentina 73.1', 'M. mountperriensis 62.1' and 'Bowenia serrulata 1.3' show high identities (98-99\%) with one another and an $84 \%$ identity with the similar sequence found in $N$. spumigena NSOR10 (Supplementary Fig. S1A). All three endosymbionts have a $21 \mathrm{bp}$ insertion (highlighted red in Supplementary Fig. S1) when compared to the $N$. spumigena NSOR10 sequence. There is a three base AAC deletion, a two base TT and a single $\mathrm{T}$ deletion across all the three endosymbiont sequences when compared to the sequences from $N$. spumigena NSOR10 (highlighted in blue in Supplementary Figure S1A).

Careful analysis of the Nostoc NdaA-C domain sequence located a region that appeared to be duplicated in a similar manner to that described in the N. spumigena NdaA-C domain sequence (Figure $4 \mathrm{~b}$ ). Each of the Nostoc NdaA-C domain sequences were divided into two sections, NdaA-C1 and its duplicate NdaA-C1b (Figure 2B), and phylogenetic analysis (Figure 4a) revealed a similar clustering of Nostoc and $N$. spumigena NdaA-C domain sequences. The NdaA-C1 domain of three endosymbionts grouped with the McyA-C1 domains of the microcystin producers and NdaA-C1 domains of the nodularin-producing strains (Figure 4a). The NdaAC1 region of Nostoc sp. 'Macrozamia riedlei 65.1' could not be amplified and was excluded from analysis. The NdaA-C1 clade was distinct from the tightly grouped clusters observed for the McyB-C1 and McyC/NdaB condensation domains, with high support of the nodes ( $71 \%$ and $81 \%$, respectively). The NdaA-C1b domains of all four ndaF carrying endosymbiont species were most similar to the NdaA-C1b homologs of N. spumigena NSOR10 and $N$. spumigena CCY9414, followed by the McyB-C2 domains of the microcystin-producing cyanobacterial species. To further demonstrate the similarity of the duplicated NdaA-C domain sequences to the respective Mcy domains, the conserved motifs within the condensation domains of NdaA of Nodularia spumigena NSOR10 and Nostoc sp. 'Macrozamia serpentine 73.1' and McyA and McyB of Microcystins aeruginosa PCC7806 were aligned (Figure 4b) (Rausch et al., 2007). The motifs C1-3 and C5, 6 and 7 are highlighted in grey with residues corresponding to the conserved motifs bolded. Due to low sequence homology, conserved motif C4 could not be easily identified. The alignment demonstrated that NdaA-C1 is homologous to McyA-C, whereas NdaA-C1b is homologous to McyB-C2. A seven amino-acid insertion was observed within the NdaA-C1 region of Nostoc sp. 'Macrozamia serpentine 73.1' just downstream of conserved domain C3 (Figure 4b). The nucleotide deletions resulted in two single amino-acid deletions in the NdaA-C1 and NdaA-C1b regions outside of the conserved domains when compared to $N$. spumigena NSOR10-derived sequence. These analyses indicated the synthesis of nodularin by some endosymbiont Nostoc spp.

\section{Bioactivity, identification and quantification of toxin from symbionts}

In order to identify cyanobiont isolates actively producing toxin, crude methanol extracts of culture material were analyzed qualitatively in the $\mathrm{PP} 2 \mathrm{~A}$ inhibition assay. Strong PP2A inhibition corresponding to approximately $10 \mu \mathrm{M}$ equivalent microcystinLR (approximately $8 \mu \mathrm{g}$ nodularin per $\mathrm{ml}$ or $8 \mu \mathrm{g}$ nodularin per g ww) was identified in the methanol extracts of Nostoc spp. 'Macrozamia riedlei 65.1' and 'Macrozamia serpentina 73.1', confirming the presence of bioactive toxins. No bioactivity was detected in extracts from Nostoc sp. 'Bowenia serrulata 1.3', Nostoc sp. 'M. mountperriensis 62.1' or Nostoc sp. 'Macrozamia macleayi 74.2'.

These samples were subsequently analyzed using HPLC, with an ESI-MS/MS, and were found to 
contain nodularin, as indicated by the $m z^{-1}$ of $825 \mathrm{Da}$. MS/MS analysis (Supplementary Figure S2A-D) confirmed the identity of nodularin by the dissociation of indicative fragmentation patterns at high collision energy (Mazur-Marzec et al., 2006). The toxin extract of Nostoc sp. 'M. serpentina 73.1' was also found to contain the nodularin variant, [L-Har ${ }^{2}$ nodularin (Supplementary Figure S2E-H). The structure of this variant was confirmed by the presence of fragmentation peaks with an increased $m z^{-1}$ of $14 \mathrm{Da}$ when compared to the data for nodularin, that were only detected when arginine residues were present. Adda was ruled out as the variable residue as neither the $\mathrm{PheCH}_{2} \mathrm{CH}\left(\mathrm{OCH}_{3}\right)$ nor $\mathrm{C}_{11} \mathrm{H}_{15} \mathrm{O}$ fragments varied from the nodularin variant fragmentation patterns (Supplementary Figure S2). Other supporting evidence included the presence of $\mathrm{L}-\mathrm{Har}$ in $\left[\mathrm{L}-\mathrm{Har}+\mathrm{H}+\mathrm{NH}_{3}\right]^{+}$(Supplementary Figure S2, peak 5), which has a $\mathrm{mz}^{-1}$ of 188 instead of 174 $\left[\mathrm{Arg}+\mathrm{H}+\mathrm{NH}_{3}\right]^{+}$, the difference of a $14 \mathrm{Da}$ moiety corresponding to the mass of the additional $\mathrm{CH}_{2}$ unit in [L-Har $\left.{ }^{2}\right]$ nodularin.

HPLC, with a heated electrospray ionization source (HESI) coupled to tandem mass spectrometry (HPLC HESI-MS/MS), was used to quantify the amount of nodularin in newly obtained extracts obtained from the Nostoc sp. 'M. riedlei 65.1' and Nostoc sp. ' $M$. serpentina 73.1' against Chl a content. A high-resolution molecular ion scan and multiple reaction monitoring scans from the precursor molecular ion of $m z^{-1}$ 825.45 Da were used to quantify the mass concentration of nodularin (Supplementary Figures S3-S5). From triplicate measurements of Nostoc sp. 'M. riedlei' 65.1 and duplicate measurements of Nostoc sp. 'M. serpentina 73.1', the mass concentrations of nodularin

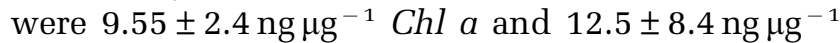
Chl a, respectively (Table 2). Further two scans, one for the precursor molecular ion $\mathrm{mz}^{-1}$ of $839.5 \mathrm{Da}$ and one for the MS/MS product ion, $m z^{-1} 767.0 \mathrm{Da}$ (Supplementary Figures S5A and S5B, spectra e-f), indicated the likely presence of [L-Har $\left.{ }^{2}\right]$ nodularin in both cultures. The absolute mass concentrations for [L-Har $\left.{ }^{2}\right]$ nodularin are not presented as a standard for this isoform was not available.

\section{Analysis of nodularin in cycad roots}

The availability of small amounts of frozen coralloid root samples from which the toxin-producing endosymbionts had been isolated allowed us to address the question: Are these toxins produced in planta? Methanol extracts of the green symbiotic ring within the remaining coralloid roots were obtained. HPLC HESI/MS/MS analysis identified the presence of nodularin in the coralloid root extract obtained from Macrozamia riedlei MZ65 (Gehringer et al., 2010) (Supplementary Figure S6), the same plant from which Nostoc sp. 'M. riedlei 65.1' was isolated. HPLC HESI-MS/MS also indicated the presence of $\left[\mathrm{L}-\mathrm{Har}^{2}\right]$ nodularin in the root extract of Macrozamia serpentina MZ73 (Gehringer et al., 2010) (Supplementary Figure S7, spectra e-f) from which the endosymbiont Nostoc sp. ' $M$. serpentina 73.1' was obtained.

Data from the $M$. riedlei 65.1 roots, using both the nodularin molecular ion and multiple reaction monitoring peak intensities, were mean centered and combined in a principal components analysis. Three replicate measurements of the root extract revealed a mean concentration of $1.34 \pm 0.74 \mathrm{ng} \mathrm{ml}^{-1}$ (Table 2). Accurate quantitation of toxin content against Chl a was not feasible as the samples had been stored at $-20^{\circ} \mathrm{C}$ for 2 years. Sample size prevented quantitation of toxin against protein content.

\section{Discussion}

Nodularin synthesis has previously been reported only in the aquatic Nodularia spumigena species and the benthic, mat-forming Nodularia sphaerocarpa strain PCC7804 (Beatti et al., 2000; Saito et al., 2001; Moffitt and Neilan, 2004; Fristachi and Sinclair, 2008). This study reports the synthesis of nodularin and [L-Har ${ }^{2}$ nodularin synthesis by terrestrial Nostoc spp. Two of the terrestrial symbiont isolates investigated in this study, Nostoc sp. 'M. serpentina 73.1' and Nostoc sp. 'M. riedlei 65.1', were confirmed genetically and chemically as nodularin producers (Tables 1 and 2, Supplementary Figures S2 and S5). The only other terrestrial symbiotic cyanobacteria reported to produce hepatotoxins are Nostoc IO-102, isolated from a lichen, and Nostoc sp. strain UK18, isolated from $P$. leucophlebia cephalodia, both of which produce microcystin (Oksanen et al., 2004; Kaasalainen et al., 2009).

Phylogenetic analysis of the AMT domain (Figure 2A) indicated that five endosymbiont species may produce a hepatotoxin. It was unable to identify whether they were capable of producing either nodularin or microcystin, as illustrated with

\footnotetext{
Figure 4 (a): Maximum likelihood phylogeny comparing the sequence similarities in the condensation domains (C) of the newly described Nostoc sp. 'Macrozamia serpentina 73.1' and representative condensation domains of NdaA, NdaB, McyA, McyB and McyC reference protein sequences. Bootstrap values greater than 50\% after 1000 resampling events are indicated at the relevant nodes. Sequences indicated by a dot were from nodularin producers. (b) Protein sequence alignment of the conserved motifs C1-3 and C5, 6 and 7 (shaded in grey) of the condensation domains NdaA-C1 and NdaA-C1b from Nodularia spumigena NSOR10 (NSOR10) and Nostoc sp. 'M. serpentine 73.1' (73.1), and the corresponding McyA-C1 and McyB-C2 domains of M. aeruginosa PCC7806 (PCC7806). Residues corresponding to the conserved motifs are in bold. A seven amino-acid insertion in the protein sequence of Nostoc sp. 'Macrozamia serpentina 73.1' when compared to N. spumigena NSOR10 is boxed.
} 
Bacillis brevis GrsA-Cl

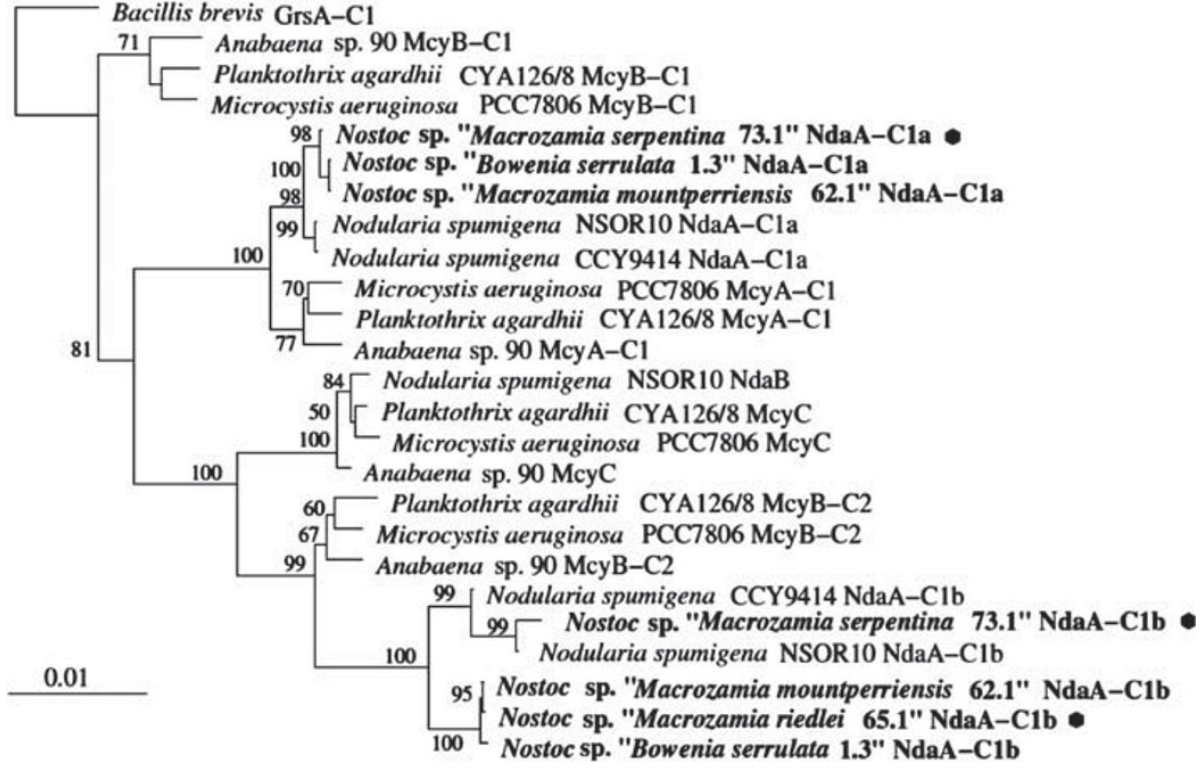

b

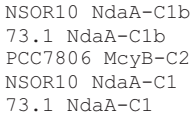

NSOR10 NdaA-C1b $73.1 \mathrm{NdaA}-\mathrm{C} 1 \mathrm{~b}$ PCC7806 MCYB-C2 NSOR10 NdaA-C1 NSOR10 NdaA-C1 PCC7806 MCYA-C1

NSOR10 NdaA-C1b $73.1 \mathrm{NdaA}-\mathrm{C} 1 \mathrm{~b}$ PCC7806 MCyB-C2 NSOR10 NdaA-C1 NSOR10 NdaA PCC7806 MCYA-C1

NSOR10 NdaA-C1b $73.1 \mathrm{NdaA}-\mathrm{C} 1 \mathrm{~b}$ PCC7806 MCYB-C2 NSOR10 NdaA-C1 NSOR10 NdaA-C1 PCC7806 MCYA-C1

NSOR10 NdaA-C1b $73.1 \mathrm{NdaA}-\mathrm{C} 1 \mathrm{~b}$ PCC7806 MсуB-C2 NSOR10 NdaA-C1 $73.1 \mathrm{NdaA}-\mathrm{C} 1$ PCC7806 MCyA-C1

NSOR10 NdaA-C1b $73.1 \mathrm{NdaA}-\mathrm{C} 1 \mathrm{~b}$ PCC7806 MCYB-C2 NSOR10 NdaA-C1 73.1 NdaA-C

PCC7806 MCYA-C1

NSOR10 NdaA-C1b $73.1 \mathrm{NdaA}-\mathrm{C} 1 \mathrm{~b}$ PCC7806 MCYB-C2 PCC7806 MCyB-C2
NSOR10 NdaA-C1 NSOR10 NdaA-C1 PCC7806 MCYA-C1

NSOR10 NdaA-C1b $73.1 \mathrm{NdaA}-\mathrm{C} 1 \mathrm{~b}$ PCC7806 MCYB-C2 NSOR10 NdaA-C1 $73.1 \mathrm{NdaA}-\mathrm{C} 1$ PCC7806 MCYA-C1
QETYETSHAQRRFYVLQQMDLNNVAYHIVSTLKIAGDFSPDVFEKAIQLLISRHESLRTSF EDAYPLARLQMGMLFHSEYSPGSAVYHNVNSFHLRVAFNESKWRIAIQELVATHAVLRTFF EDAYPLARLQMGMLFHSEYSPGSAVYHNVNSF HLRVVF DESKWRIAVQELVANHSVLRTFFD EDAYPLTALQLGMIFHSEYQGNLSVYHDVFTYHIRADFSFPALHSAIQEIVQRHPVLRTSFA C1 C2

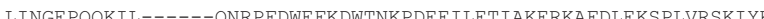

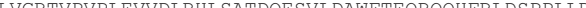
VSNFSEPL VSNTSELLURRIVRVPLVVDIRHISVADQESILAWVAERKQHERLDSPPLIRFHHR

---------------FNLHLLEPD----QTAISNAQTSQFHLQQIALN-----TDAVW FTLHLLEPD----KTAISHAQSO-SIOQIELN-----TDAVW LS PNEY ILELE I HHI ICDGWSMSLLAKECLQYYSDLAKGLQPNIEPLPIQYK------DYAG RTDETFOLTLIFHHAIIDGWSVGLLFTELLORYLSLLGEEIVLLNPPP-_---_-NIAFRD RSDETFOL TITHHAT RSDETQLTLA

QSNIFPSEDSNKHLDYWRKQLEDGQI PRVHLPTDFHRP--PVKTFNGSRLNWTFTPEILSGL SSNI LPNEKHKKHLDYWROOLNDGQL PRVHLPTDFHRP--PTKTFNVSRLNWTFOPEI ISGI ONNLLRSENNSKTLDYWREKLDNGOITRVHLPTDFKRP--OIKTFKGSHLSWKFTOETISKI VALEOTAINSPEYOQHWT EKIKDTTTTKI PRWSOSDRSSEPENLKTIGTHEVTI SITVSHCL IAT IALLQKALNSQCRQHWLKLNGITITKLPRTPQSYHSHEPE-LGILGTQEITLSLIVSQG

QMICQQTETTLFMGLIAAVKVLLYRYSGQQDITIGTEIASSN-------------TLVIR RTICNQTETTLFMGLVAAVKVLLYRYSGQHDIAIGTEITTRNNYQLASSS--QFLNTVVIRD RKSCQENEITLFMALVAAVKILLYRYSGQHDITIGTEIATRNHPQLQ-SLIGLFLNTLVIR KQVANQAGVTLKSLLLAAHLKVLSVLFNOSDVLTGLVSNGRSEEADGERVLGLFLNTLPLR KOVANKAGVTLKSVLLAAHMKVLSVLFNOSDVLTGMVSNGRPEEADGERVLGLFLNTLPLR KQLGKQVGVPLKSVLLAAHFRVLSLLNNQRDIVTGLVSNGRLEAADGEKILGLFLNTLPLRI C5

KLEPEQGYKNLLIQVSQTITEAFEHSNYPFELLVKELATSSE INRTPFFDVLVLLQNLSPSV EIEPDRGYQNLLIKVRQTVTEALEHSAYPFDILVKELANSSE INRTPLFDVLVLLQNISOPV QIEPEKGYKNLLAKVROTVTEALEHSDYPFDILVEKLAVSRE INRTPLFDTLVLLONFEOSV OLLGGT-WIDLMOETFKAERESLPFRRYPLADLOWNLGGOPLFETSFNFTHFHVYHS I LGI QLLGGT-WIDIMOETEKAFRESI PFRRYPLADIOWNLGCQPL (1) $\mathrm{C} 6 \& 7$

D-EEI--OIKSLGSLDDLNKFDLSFVFIEONNELSLALIYNTDIFOAERIOOALRHLDKLLIEM GLENIOIKSLDSLTPTSKFDLSFVFSEDEEKLRLEL IYNTDLFQEERMKKCL IHFDKLLNEM GLOVLESKFLGKTN--FTLGVHFSLDLFSSOINLTLKYNASELCOOOAIAIGNYYTNTLTAI GLQVLDSKFLGKTN--FTLGVHFS LDLVSSQI HLTLKYNASELCQEQA IA I GNYYTSTLAAI DLEVLGGKFFNQTN--FTLLANFSLHPLSSQIELTLKYDGNYLGEKQMELIGGYYEKTLIAM

LANPSQAVCAI

IVNPSQPVCKI

LSNPAQPVKDI

ASDPLQRYDS-

ASDPSQRYES -

ATEGLERYETC 
the positioning of the AMT sequence from the microcystin producer, Nostoc 152 with the nodularin-producing Nodularia species. The positioning of the AMT domain sequence of Nostoc sp. Macrozamia macleayi 74.2 within the microcystin producing Microcystis cluster would suggest that this endosymbiont carries at least part of the mcy cluster. This positioning on the AMT tree would be consistent with the studies of Oksanen et al. (2004) and Kaasalainen et al. (2009) who demonstrated microcystin production in Nostoc symbionts found in lichens. A bioassay utilizing PP2A indicated that only extracts from two cyanobiont isolates inhibited the eukaryotic protein phosphatase, namely Nostoc sp. 'M. serpentina 73.1' and Nostoc sp. 'M. riedlei 65.1'. The lack of bioactivity in the remaining three AMT-carrying symbiont isolates would suggest that they may carry non-functional mcy/nda gene clusters, express toxin at levels below assay detection limits or produce a novel microcystin or nodularin congener that does not inhibit PP2A. In addition, two of the Nostoc isolates demonstrating no bioactivity in the PP2A assay, Nostoc spp. 'Bowenia serrulata 1.3' and 'Macrozamia mountperriensis 62.1', also had frame-shift mutations in their aminotransferase sequences that may have contributed to their non-toxic phenotype.

The synthesis of both nodularin and [L-Har $\left.{ }^{2}\right]$ nodularin in these cyanobacterial isolates presented the opportunity to study the mechanistics of toxin production. Sequencing of the partial nda cluster in Nostoc sp. 'Macrozamia serpentina 73.1' revealed identical domain structures for $\mathrm{NdaA}$ and $\mathrm{NdaB}$ as seen in N. spumigena NSOR10. However, additional sequencing is required to confirm if the remaining PKS and NRPS domains are conserved in Nostoc sp. 'Macrozamia serpentina 73.1'. It has been proposed that changes in the substrate-binding pocket of the terminal adenylation domain of $\mathrm{NdaB}$ may allow for more flexibility of binding for the activation and incorporation of L-Har into nodularin during biosynthesis (Moffitt and Neilan, 2004). Nostoc sp. ' $M$. serpentina 73.1', that produces both nodularin and [L-Har ${ }^{2}$ nodularin, has an NdaB-binding pocket sequence identical to that found in nodularin producers but differs from the other [L-Har $\left.{ }^{2}\right]$ nodularin producer, Nodularia sphaerocarpa PCC7804 (Table 1). Our analysis indicated that the asparagine to serine substitution is not essential for [L-Har $\left.{ }^{2}\right]$ nodularin synthesis, and that the binding pocket sequence DVWNFGFV provides sufficient molecular space for the incorporation of the larger L-Har residue.

The identification of a novel nodularin-synthesizing cyanobacterial species other than Nodularia spp. raises questions as to the evolutionary origin of the nda cluster. This cluster differs from the mcy gene cluster as it does not carry the NRPS modules responsible for the incorporation of the amino acids D-Ala and L-Leu (Moffitt and Neilan, 2004). Analysis of the partial condensation domain DNA sequences of the ndaA-C1 and ndaA-C1b genes of the toxin-producing Nostoc sp. 'M. serpentina 73.1', as well as the AMT carrying endosymbiont strains Nostoc sp. 'Bowenia serrulata 1.3' and Nostoc sp. 'Macrozamia riedlei 62.1', revealed the identical condensation motif repeat present in $N$. spumigena NSOR10 (Figure 4b and Supplementary Figure S1A). This suggested that the genetic event generating the nda cluster was the same for all nodularinproducing strains investigated to date. An identical insertion of seven amino acids was observed in the NdaA-C1 domains of all nda-carrying endosymbiont strains sequenced and was not present in the NdaAC1 domain of $N$. spumigena NSOR10. This seven amino-acid insertion was also not observed in the McyA-C1 protein sequence derived from $M$. aeruginosa PCC7806 (Figure 4b) from which the NdaA-C1 domain is thought to have originated. This would suggest that the seven amino-acid insertion probably occurred after the proposed mcy truncation event and after transfer of the nda cluster into Nostoc and Nodularia species. The protein alignment in Figure $4 \mathrm{~b}$ and DNA alignment of Supplementary Fig S1A would suggest that the nda cluster was first transferred into Nodularia spumigena species, as all the endosymbionts carry the identical $21 \mathrm{bp}$ insertion and 6 nucleotide deletions. Analysis of the condensation domains of NdaA, McyA and McyB (Figure 4) demonstrate high similarity between the endosymbiont-derived protein sequence and that of $N$. spumigena NSOR10. This suggests that the duplicated sequence within the NdaA-C domain of Nostoc sp. 'Macrozamia serpentina 73.1' may have evolved from the fusion of a McyA-C domain and the McyB-C2 domain following deletion of two NRPS modules from mcy, in the same manner as proposed for the nodularin-producing $N$. spumigena (Moffitt and Neilan, 2004). This study thereby provides support for the common origin of the nda cluster, however, it cannot offer support as to the order of recombination and transfer of the $n d a$ cluster to Nodularia spp.

The observation that the toxin-producing endosymbiont AMT regions do not show good sequence similarity to the AMT sequences found in nodularin-producing Nodularia spp. (Figure 2A), would suggest that the evolution of the $n d a$ cluster in Nostoc spp. is not straightforward. Additional sequencing of the nda clusters is required before further sequence and phylogenetic analysis can be undertaken. Whether the genetic event generating the nda cluster occurred in a Nodularia, Microcystis or another species of cyanobacteria, remains an enigma. What is evident from the alignment of the DNA sequences spanning the potential deletion site is that all nda carrying endosymbiont Nostoc species and the nda carrying $N$. spumigena NSOR10 show high similarity, thereby suggesting a similar evolutionary origin.

Tandem MS analysis indicated the production of nodularin and not microcystin in the two strains 
showing bioactivity in the PP2A assay. Data on product ion spectra (S2) confirmed that the synthesis of $\left[\mathrm{L}-\mathrm{Har}^{2}\right]$ nodularin as well. Nodularin was further confirmed by HPLC HESI-MS/MS at low concentrations (Table 2) in extracts of the cyanobionts cultures. The levels of toxin produced by these endosymbionts are low, with a $\mu \mathrm{g}$ : $\mu \mathrm{g}$ ratio of nodularin:Chl $a$ of $0.01: 1$, when compared to the nodularin producing abilities of Nodularia KAC66, an aquatic isolate, with ratios ranging between 0.4:1 and 0.7:1 (Stolte et al., 2002). The discrepancy between nodularin levels detected by the PP2A assay (about $8 \mu \mathrm{g} \mathrm{ml}^{-1}$ ) versus the HPLC HESI-MS/ MS (over $100 \mathrm{ng} \mathrm{ml}^{-1}$ ) could be ascribed to differences in the assay procedures. The PP2A would reflect the influence of all the hepatotoxins in an extract on the enzyme, that is, nodularin and the potential inhibition by [L-Har $\left.{ }^{2}\right]$ nodularin, whereas the HESI-MS/MS reflects the nodularin concentration only. The PP2A assay was standardized against microcystin-LR, whereas nodularin was used to establish a standard curve for HESI-MS/MS. In addition, the HESI-MS/MS nodularin quantitation was completed 2 years after the PP2A quantitation and the cultures may have altered their toxin profile and levels of production.

Nodularin was detected in planta in extracts of the cycad roots that yielded the endosymbiont Nostoc sp. ' $M$. riedlei 65.1', while [L-Har'] nodularin was only present in root extracts that contained Nostoc sp. 'M. serpentina 73.1' (Supplementary Figures S6 and S7). Nodularin production was not observed in the root extracts of Macrozamia serpentina (MZ73) (Supplementary Figure S7, spectra a-d). Although the symbiont Nostoc sp. 'M. serpentina 73.1' synthesized nodularin, the quantities were significantly lower than that seen for [L-Har'] nodularin (Supplementary Figure S5, Table 2). The lack of amplification of mcyE/ndaF genes from plant material not containing cyanobacterial symbionts indicates that this toxin cannot be of plant origin. The concentration of nodularin in the coralloid root tissue of Macrozamia riedlei (MZ65) can be approximated as $3 \mathrm{pmolg}^{-1}$ (for a single sample of approximately $500 \mathrm{mg}$ ). Lehtimäki et al. (2011) demonstrated signs of oxidative stress in young spinach plants irrigated with nodularin-containing water and detected toxin in young roots in the range of $0-24 \mathrm{pmolg}^{-1}$. This would suggest that, at least locally, nodularin would induce oxidative stress in the coralloid root tissue. Whether the toxin is transported to the rest of the plant or restricted to the coralloid root, remains to be elucidated.

Research into the toxic effects of nodularin has been largely over-shadowed by studies on the biological effects of microcystin (Humpage, 2008). Given that both toxins inhibit protein phosphatases, it is thought that they exhibit similar biological activities (Mackintosh et al., 1990; Honkanen et al., 1991). The different structures of nodularin has leant itself to the theory that it can target different tissues than those effected by microcystin (Ohta et al., 1994) and therefore induce different toxicological effects in exposed animals and potentially plants. This study has demonstrated the production of nodularin in planta at levels capable of inducing oxidative stress in spinach plant root tissue (Lehtimaki et al., 2011). Whether these effects can be extended to include cycad roots remains to be determined. The nodularin-producing Nostoc spp. produce toxin at levels over 100-fold lower than that observed for the aquatic, nodularin-producing Nodularia sp. Toxin released into an aquatic environment would be immediately diluted, thereby reducing the immediate toxic effects on the aquatic biota. In contrast, toxin released into a drier environment, and possibly in planta, would not be diluted and may accumulate. Whether these levels of hepatotoxin production are significant in a terrestrial environment remains to be investigated. Further research into the ancient relationship between cyanobacteria and the Cycadacea should reveal the molecular interactions between toxin and host plant, and also highlight the evolutionary importance of secondary metabolism in symbioses and the terrestrial environment.

\section{Acknowledgements}

This work was funded by Grant \#265-605 of the Australian Biodiversity and Resources Programme and Grant Number \#FF0883440 from the Australian Research Council. We thank Andreas Rueckert of the Department of Biological Sciences, University of Waikato, for providing DNA from $M$. aeruginosa CYN10, and Brynn Hibbert of the Department of Chemistry, University of New South Wales, for help with statistical analyses. All mass spectrometric analyses were carried out at the Bioanalytical Mass Spectrometry Facility, UNSW and were supported in part by infrastructure funding from the New South Wales Government as a part of its co-investment in the National Collaborative Research Infrastructure Strategy. We would like to thank the reviewers for their constructive comments in improving this manuscript.

\section{References}

Abe T, Lawson T, Weyers JDB, Codd GA. (1996). Microcystin-LR inhibits photosynthesis of Phaseolus vulgaris primary leaves: implications for current spray irrigation practice. New Phytol 133: 651-658.

Bachmann BO, Ravel J. (2009). Methods for in silico prediction of microbial polyketide and non-ribosomal peptide biosynthetic pathways from DNA sequence data. Method Enzymol 458: 181-217.

Barker GLA, Hayes PK, O’Mahony SL, Vacharapiyasophon P, Walsby AE. (1999). A molecular and phenotypic analysis of Nodularia (cyanobacteria) from the Baltic Sea. J Phycol 35: 931-937.

Beattie KA, Kaya K, Codd GA. (2000). The cyanobacterium Nodularia in PCC 7804, of freshwater origin, produces L-Har(2) nodularin. Phytochemistry 54: 57-61. 
Bergman B, Rai AN, Rasmussen U. (2007). Cyanobacterial associations. In Elmerich C, Newton WE (eds.) Associative and Endophytic Nitrogen Fixing Bacteria and Cyanobacterial Associations. Springer: Dordrecht, The Netherlands, pp 257-301.

Challis GL, Ravel J, Townsend CA. (2000). Predictive, structure-based model of amino acid recognition by nonribosomal peptide synthetase adenylation domains. Chem Biol 7: 211-224.

Christiansen G, Fastner J, Erhard M, Borner T, Dittmann E. (2003). Microcystin biosynthesis in Planktothrix: genes, evolution, and manipulation. J Bacteriol 185: 564-572.

De Silva ED, Williams DE, Andersen RJ, Klix H, Holmes CFB, Allen TM. (1992). Motuporin, a potent protein phosphatase inhibitor isolated from the Papau-NewGuinea sponge Theonella-swinhei gray. Tetrahedron Lett 33: 1561-1564.

Fewer DP, Jokela J, Rouhiainen L, Wahlsten M, Koskenniemi K, Stal LJ et al. (2009). The non-ribosomal assembly and frequent occurrence of the protease inhibitors spumigins in the bloom-forming cyanobacterium Nodularia spumigena. Mol Microbiol 73: 924-937.

Fewer DP, Rouhiainen L, Jokela J, Wahlsten M, Laakso K, Wang $\mathrm{H}$ et al. (2007). Recurrent adenylation domain replacement in the microcystin synthetase gene cluster. BMC Evol Biol 7: 183-194.

Fewer DP, Tooming-Klunderud A, Jokela J, Wahsten M, Rouhiainen L, Kristensen $\mathrm{T}$ et al. (2008). Natural occurrence of microcystin synthetase deletion mutants capable of producing microcystins in strains of the genus Anabaena (Cyanobacteria). MicrobiologySgm 154: 1007-1014.

Fristachi A, Sinclair J. (2008). Occurrence of cyanobacterial harmful algal blooms: workgroup report. In Hudnell HK (eds.) Cyanobacterial Harmful Algal Blooms: State of the Science and Research Needs. Springer: New York, USA, pp 45-103.

Gehringer MM, Kewada V, Coates N, Downing TG. (2003). The use of Lepidium sativum in a plant bioassay system for the detection of microcystin-LR. Toxicon 41: 871-876.

Gehringer MM, Pengelly JJL, Cuddy WS, Fieker C, Forster PI, Neilan BA. (2010). Host selection of symbiotic cyanobacteria in 31 species of the Australian cycad genus: Macrozamia (Zamiaceae). Mol Plant-Microbe Interact 23: 811-822.

Guindon S, Dufayard JF, Hordijk W, Lefort V, Gascuel O. (2009). PhyML: fast and accurate phylogeny reconstruction by maximum likelihood. Infect Genet Evol 9: 384-385.

Halinen K, Fewer DP, Sihvonen LM, Lyra C, Eronen E, Sivonen K.. (2008). Genetic diversity in strains of the genus Anabaena isolated from planktonic and benthic habitats of the Gulf of Finland (Baltic Sea). FEMS Microbiol Ecol 64: 199-208.

Honkanen RE, Dukelow M, Zwiller J, Moore RE, Khatra BS, Boynton AL.. (1991). Cyanobacterial nodularin is a potent inhibitor of type-1 and type-2A protein phosphatases. Mol Pharmacol 40: 577-583.

Humpage A. (2008). Toxin types, toxiconkinetics and toxicodynamics. In Hudnell HK (eds.) Cyanobacterial Harmful Algal Blooms: State of the Science and Research Needs. Springer: New York, USA, pp. 383-415.

Jungblut AD, Neilan BA. (2006). Molecular identification and evolution of the cyclic peptide hepatotoxins, microcystin and nodularin, synthetase genes in three orders of cyanobacteria. Arch Microbiol 185: 107-114.

Kaasalainen U, Jokela J, Fewer DP, Sivonen K, Rikkinen J. (2009). Microcystin production in the Tripartite Cyanolichen Peltigera leucophlebia. Mol PlantMicrobe Interact 22: 695-702.

Kaneko T, Nakajima N, Okamoto S, Suzuki I, Tanabe Y, Tamaoki $\mathrm{M}$ et al. (2007). Complete genomic structure of the bloom-forming toxic cyanobacterium Microcystis aeruginosa NIES-843. DNA Res 14: 247-256.

Kuiper-Goodman T, Falconer I, Fitzgerald J. (1999). Human health aspects. In Chorus I, Bartram J (eds.) Toxic Cyanobacteria in Water: A Guide to Public Health Consequences, Monitoring and Management. E\& FN Spon: London, UK, pp 114-141.

Lehtimaki J, Sivonen K, Luukkainen R, Niemela SI. (1994). The effects of incubation-time, temperature, light, salinity and phosphorus on growth and hepatotoxin production by Nodularia strains. Archiv Fur Hydrobiologie 130: 269-282.

Lehtimaki N, Shunmugam S, Jokela J, Wahlsten M, Carmel $\mathrm{D}$, Keranen $\mathrm{M}$ et al. (2011). Nodularin uptake and induction of oxidative stress in spinach (Spinachia oleracea). J Plant Physiol 168: 594-600.

Lindblad P, Atkins CA, Pate JS. (1991). N-2-fixation by freshly isolated Nostoc from coralloid roots of the cycad Macrozamia-riedlei (Fisch-ex-Gaud) Gardn. Plant Physiol 95: 753-759.

Lyra C, Suomalainen S, Gugger M, Vezie C, Sundman P, Paulin L et al. (2001). Molecular characterization of planktic cyanobacteria of Anabaena, Aphanizomenon, Microcystis and Planktothrix genera. Int J Syst Evol Microbiol 51: 513-526.

Mackintosh C, Beattie KA, Klumpp S, Cohen P, Codd GA. (1990). Cyanobacterial microcystin-LR is a potent and specific inhibitor of protein phosphatase- 1 and phosphatase-2A from both mammals and higher plants. FEBS Lett 264: 187-192.

Mazur-Marzec H, Meriluoto J, Plinski M, Szafranek J. (2006). Characterization of nodularin variants in Nodularia spumigena from the Baltic Sea using liquid chromatography/mass spectrometry/mass spectrometry. Rapid Commun Mass Sp 20: 2023-2032.

McElhiney J, Lawton LA, Leifert C. (2001). Investigations into the inhibitory effects of microcystins on plant growth, and the toxicity of plant tissues following exposure. Toxicon 39: 1411-1420.

Meeks JC, Castenholz RW. (1971). Growth and photosynthesis in an extreme thermophile, Synechococcus lividus (Cyanophyta). Arch Microbiol 78: 25-41.

Moffitt MC, Blackburn SI, Neilan BA. (2001). rRNA sequences reflect the ecophysiology and define the toxic cyanobacteria of the genus. Nodularia Int J Syst Evol Microbiol 51: 505-512.

Moffitt MC, Neilan BA. (2004). Characterization of the nodularin synthetase gene cluster and proposed theory of the evolution of cyanobacterial hepatotoxins. Appl Environ Microbiol 70: 6353-6362.

Mohamed ZA, Al Shehri AM. (2009). Microcystins in groundwater wells and their accumulation in vegetable plants irrigated with contaminated waters in Saudi Arabia. J Hazard Mater 172: 310-315.

Namikoshi M, Choi BW, Sakai R, Sun F, Rinehart KL, Carmichael WW et al. (1994). New nodularins - a general method for structure assignment. J Org Chem 59: 2349-2357. 
Neilan BA, Dittmann E, Rouhiainen L, Bass RA, Schaub V, Sivonen K. et al. (1999). Nonribosomal peptide synthesis and toxigenicity of cyanobacteria. I Bacteriol 181: 4089-4097.

Nishizawa T, Asayama M, Fujii K, Harada K, Shirai M. (1999). Genetic analysis of the peptide synthetase genes for a cyclic heptapeptide microcystin in Microcystis spp. J Biochem 126: 520-529.

Ohta T, Sueoka E, Iida N, Komori A, Suganuma M, Nishiwaki R et al. (1994). Nodularin, a potent inhibitof of protein phosphatase- 1 and phosphatase-2A, is a new environmental carcinogen in male F344 rat-liver. Cancer Res 54: 6402-6406.

Oksanen I, Jokela J, Fewer DP, Wahlsten M, Rikkinen J, Sivonen K.. (2004). Discovery of rare and highly toxic microcystins from lichen-associated cyanobacterium Nostoc sp strain IO-102-I. Appl Environ Microbiol 70: 5756-5763.

Peuthert A, Lawton L, Pflugmacher S. (2008). In vivo influence of cyanobacterial toxins on enzyme activity and gene expression of protein phosphatases in Alfalfa (Medicago sativa). Toxicon 52: 84-90.

Pflugmacher S, Hofmann J, Hubner B. (2007). Effects on growth and physiological parameters in wheat (Triticum aestivum l.) grown in soil and irrigated with cyanobacterial toxin contaminated water. Environ Toxicol Chem 26: 2710-2716.

Rai AN, Soderback E, Bergman B. (2000). Cyanobacteriumplant symbioses. New Phytol 147: 449-481.

Rantala A, Fewer DP, Hisbergues M, Rouhiainen L, Vaitomaa J, Borner $\mathrm{T}$ et al. (2004). Phylogenetic evidence for the early evolution of microcystin synthesis. Proc Natl Acad Sci USA 101: 568-573.

Rausch C, Hoof I, Weber T, Wohlleben W, Huson DH. (2007). Phylogenetic analysis of condensation domains in NRPS sheds light on their functional evolution. BMC Evol Biol 7: 78.

Rausch C, Weber T, Kohlbacher O, Wohlleben W, Huson DH. (2005). Specificity prediction of adenylation domains in nonribosomal peptide synthetases (NRPS) using transductive support vector machines (TSVMs). Nucleic Acids Res 33: 5799-5808.

Rinehart KL, Harada K, Namikoshi M, Chen C, Harvis CA, Munro MHG et al. (1988). Nodularin, microcystin and the configuration of ADDA. J Am Chem Soc 110: 8557-8558.

Rouhiainen L, Sivonen K, Buikema WJ, Haselkorn R. (1995). Characterisation of toxin-producing cyanobacteria by using an oligonucleotide probe containing a tandemly repeated heptamer. J Bacteriol 177: 6021-6026.

Rouhiainen L, Vakkilainen T, Siemer BL, Buikema W, Haselkorn R, Sivonen K. (2004). Genes coding for hepatotoxic heptapeptides (microcystins) in the cyanobacterium Anabaena strain 90. Appl Environ Microbiol 70: 686-692.
Rounge TB, Rohrlack T, Nederbragt AJ, Kristensen T, Jakobsen KS. (2009). A genome-wide analysis of nonribosomal peptide synthetase gene clusters and their peptides in a Planktothrix rubescens strain. BMC Genomics 10: 396.

Rueckert A, Cary SC. (2009). Use of an armored RNA standard to measure microcystin synthetase E gene expression in toxic Microcystis sp by reversetranscription qPCR. Limnol Oceanograph Meth 7: 509-520.

Saito K, Konno A, Ishii H, Saito H, Nishida F, Abe T et al. (2001). Nodularin-Har: a new nodularin from Nodularia. J Nat Prod 64: 139-141.

Saqrane S, El Ghazali I, Oudra B, Bouarab L, Vasconcelos V. (2008). Effects of cyanobacteria producing microcystins on seed germination and seedling growth of several agricultural plants. J Environ Sci Health B43: 443-451.

Siebert PD, Chenchik A, Kellogg DE, Lukyanov KA, Lukyanov SA. (1995). An improved method for walking in uncloned genomic DNA. Nucleic Acids Res 23: 1087-1088.

Spoof L, Vesterkvist P, Lindholm T, Meriluoto J. (2003). Screening for cyanobacterial hepatotoxins, microcystins and nodularin in environmental water samples by reversed-phase liquid chromatography-electrospray ionisation mass spectrometry. J Chromatogr 1020: 105-119.

Stolte W, Karlsson C, Carlsson P, Granéli E. (2002). Modeling the increase of nodularin content in Baltic Sea Nodularia spumigena during stationary phase in phosphorous- limited batch cultures. FEMS Microbiol Ecol 41: 211-220.

Thompson JD, Gibson TJ, Plewniak F, Jeanmougin F, Higgins DG. (1997). The CLUSTAL_X windows interface: flexible strategies for multiple sequence alignment aided by quality analysis tools. Nucleic Acids Res 25: 4876-4882.

Tillett D, Dittmann E, Erhard M, von Dohren H, Borner T, Neilan BA.. (2000). Structural organization of microcystin biosynthesis in Microcystis aeruginosa PCC7806: an integrated peptide-polyketide synthetase system. Chem Biol 7: 753-764.

Tillett D, Neilan BA. (2000). Xanthogenate nucleic acid isolation from cultured and environmental cyanobacteria. J Phycol 36: 251-258.

Tooming-Klunderud A, Fewer DP, Rohrlack T, Jokela J, Rouhiainen L, Sivonen K et al. (2008). Evidence for positive selection acting on microcystin synthetase adenylation domains in three cyanobacterial genera. BMC Evol Biol 8: 256-276.

Ward CJ, Beattie KA, Lee EYC, Codd GA. (1997). Colorimetric protein phosphatase inhibition assay of laboratory strains and natural blooms of cyanobacteria: comparisons with high-performance liquid chromatographic analysis for microcystins. FEMS Microbiol Lett 153: 465-473.

Supplementary Information accompanies the paper on The ISME Journal website (http://www.nature.com/ismej) 